Review

\title{
Ecosystem-based marine spatial management: Review of concepts, policies, tools, and critical issues
}

\author{
Stelios Katsanevakis ${ }^{\mathrm{a}, *}$, Vanessa Stelzenmüller ${ }^{\mathrm{b}}$, Andy South ${ }^{\mathrm{c}}$, Thomas Kirk Sørensen ${ }^{\mathrm{d}}$, Peter J.S. Jones ${ }^{\mathrm{e}}$, \\ Sandy Kerr ${ }^{\mathrm{f}}$, Fabio Badalamenti ${ }^{\mathrm{g}}$, Christos Anagnostou ${ }^{\mathrm{a}}$, Patricia Breen ${ }^{\mathrm{c}}$, Guillem Chust ${ }^{\mathrm{h}}$, \\ Giovanni D’Anna ${ }^{g}$, Mike Duijn ${ }^{i}$, Tatiana Filatova ${ }^{j}$, Fabio Fiorentino ${ }^{g}$, Helena Hulsman ${ }^{j}$, Kate Johnson ${ }^{f}$, \\ Aristomenis P. Karageorgis ${ }^{\mathrm{a}}$, Ingrid Kröncke ${ }^{\mathrm{k}}$, Simone Mirto ${ }^{\mathrm{g}}$, Carlo Pipitone ${ }^{\mathrm{g}}$, Susan Portelli ${ }^{\mathrm{l}}$, Wanfei Qiu ${ }^{\mathrm{e}}$, \\ Henning Reiss ${ }^{\mathrm{k}}$, Dimitris Sakellariou ${ }^{\mathrm{a}}$, Maria Salomidi ${ }^{\mathrm{a}}$, Luc van Hoof ${ }^{\mathrm{m}}$, Vassiliki Vassilopoulou ${ }^{\mathrm{a}}$, \\ Tomás Vega Fernández ${ }^{\mathrm{g}}$, Sandra Vöge ${ }^{\mathrm{k}}$, Anke Weber ${ }^{\mathrm{n}}$, Argyro Zenetos ${ }^{\mathrm{a}}$, Remment ter Hofstede ${ }^{\mathrm{m}}$ \\ ${ }^{a}$ Hellenic Center for Marine Research (HCMR), 46.7 km Athens-Sounio, 19013 Anavyssos, Greece \\ ${ }^{\mathrm{b}}$ vTI Institute of Sea Fisheries, Palmaille 9, 22767 Hamburg, Germany \\ ${ }^{\mathrm{c}}$ Cefas, Pakefield Road, Lowestoft, Suffolk, NR33 OHT, UK \\ ${ }^{\mathrm{d}}$ Technical University of Denmark, National Institute of Aquatic Resources (DTU AQUA), Charlottenlund Castle, 2920 Charlottenlund, Denmark \\ e Department of Geography, UCL, Pearson Building, Gower Street, London WC1E 6BT, UK \\ ${ }_{\mathrm{f}}^{\mathrm{f}}$ International Centre for Island Technology, Heriot-Watt University, Old Academy, Stromness, Orkney KW16 3AW, UK \\ ${ }^{\mathrm{g}}$ CNR-IAMC, Via Giovanni da Verrazzano 17, 91014 Castellammare del Golfo (TP), Italy \\ ${ }^{\mathrm{h}}$ AZTI - Tecnalia / Marine Research Division, Txatxarramendi ugartea z/g, 48395 Sukarrieta, Spain \\ ${ }^{\mathrm{i}}$ TNO, Bouw en Ondergrond, Van Mourik Broekmanweg 6, Postbus 49, 2600 AA Delft, Netherlands \\ ${ }^{\mathrm{j}}$ Deltares, Scenarios and Policy Analysis Unit, Postbus 85467, 3508 AL Utrecht, Netherlands \\ ${ }^{\mathrm{k}}$ Senckenberg am Meer, Marine Research Department, Südstrand 40, 26382 Wilhelmshaven, Germany \\ ${ }^{1}$ Fisheries Control Section, Ministry for Resources and Rural Affairs (MRRA), Barriera Wharf, Valletta, Malta \\ ${ }^{\mathrm{m}}$ Institute for Marine Resources and Ecosystem Studies (IMARES), P.O. Box 68, 1970 AB, IJmuiden, Netherlands \\ ${ }^{\mathrm{n}}$ Norwegian Institute for Water Research (NIVA), P.O. Box 1266 Pirsenteret, 7462 Trondheim, Norway
}

\section{A R T I C L E I N F O}

Article history:

Available online 16 September 2011

\begin{abstract}
A B S T R A C T
Conventional sectoral management and piecemeal governance are considered less and less appropriate in pursuit of sustainable development. Ecosystem based marine spatial management (EB-MSM) is an approach that recognizes the full array of interactions within an ecosystem, including human uses, rather than considering single issues, species, or ecosystem services in isolation. Marine spatial planning and ocean zoning are emerging concepts that can support EB-MSM. EB-MSM is driven by high-level goals that managers aim to achieve through the implementation of measures. High-level goals and objectives need to be translated into more operational objectives before specific targets, limits and measures can be elaborated.
\end{abstract}

Abbreviations: AGORA, Assessment of Group Options with Reasonable Accord; BT, Benefits Transfer; CBA, Cost Benefit Analysis; CBD, Convention on Biological Diversity; CFP, Common Fisheries Policy (EU); CM, Choice Modelling; CV, Contingent Valuation; EB-MSM, Ecosystem-Based Marine Spatial Management; EIA, Environmental Impact Assessment; FAO, Food and Agriculture Organization; GES, Good Environmental Status; ICES, International Council for the Exploration of the Sea; ICZM, Integrated Coastal Zone Management; IUCN, International Union for the Conservation of Nature; MCA, Multi-Criteria Analysis; JRC, Joint Research Center; MESMA, Monitoring and Evaluation of Spatially Managed Areas (EU funded research project); MPA, Marine Protected Area; MSFD, Marine Strategy Framework Directive (EU); MSP, Marine Spatial Planning; OP, Opinion Polling; OZ, Ocean Zoning; RP, Revealed Preference; SEA, Strategic Environmental Assessment Directive (EU); SMART, Specific-Measurable-Achievable-Realistic-Time bound; SP, Stated Preference; TEV, Total Economic Value; UNCLOS, United Nations Convention on the Law of the Sea; WFD, Water Framework Directive (EU).

* Corresponding author. Tel.: +30 210 9856701; fax: +30 2109811713.

E-mail address: stelios@katsanevakis.com (S. Katsanevakis). 
Monitoring, evaluation and adaptation are necessary to ensure that marine management measures are both effective and efficient. Solid monitoring frameworks are the foundation of adaptive management, as they provide the necessary information to evaluate performance and the effectiveness of management actions. Marine protected areas (MPAs) - possibly set up in networks - constitute a key component in EBMSM policies and practises and have been applied as a cornerstone in conservation of marine biodiversity, management of fish populations, development of coastal tourism, etc. Moreover, MPA experiences have provided methods and concepts (such as zoning) to a wider EB-MSM context. The assignment of values to biophysical features of the marine environment allows the direct assessment of related management choices and may assist EB-MSM.

A range of monetary valuation techniques have been proposed to reduce attributes of goods and services to a single metric. However, in the marine environment such an approach is often over simplistic, and thus less reductive techniques may be necessary. Rather than producing a single metric, the results of non-monetary assessments guide policy allowing weight to be given as necessary to potential areas of conflict and consensus.

Strategies to take into account climate change effects and geohazard risks in EB-MSM have been applied or proposed worldwide. EB-MSM regimes must be alert to such risks and flexible to account for changes.

(C) 2011 Elsevier Ltd. All rights reserved.

\section{Introduction}

Humanity has benefited enormously from the rapid economic and technological developments of the last century. However, much of this progress has been achieved to the detriment of natural systems and the sustainability of resources and ecosystem functions. Our oceans and coastal areas in particular have been and continue to be affected by a heavy burden of anthropogenic pressures. Humans depend on marine ecosystems for important and valuable goods and services, but human use has also altered the marine environment through direct and indirect means. There is widespread degradation of marine habitats, depletion of resources and loss of biodiversity at the levels of ecosystems, species and genes. No areas of the ocean, even the most remote ones, are completely untouched by human activities (Halpern et al., 2008a).

The increasing pressures upon the marine realm call for a well planned approach of managing use of marine space. Fisheries and aquaculture, offshore wind farms, gas and oil industry, coastal defence systems, extraction of building materials, shipping, tourist industry, and the need for marine conservation all compete for the same valuable space. This is aggravated by the fact that climate change will influence the structure and functioning of marine ecosystems and the use of coastal zones, calling for a robust approach of future spatial planning that also takes cross-boundary developments into account.

The human uses of the sea have been spatially managed for decades. Fisheries have been opened or closed in particular areas; marine transportation has been managed within designated lanes or zones especially in intensively used areas; rights to explore and exploit energy and mineral resources have been leased on an area basis; marine protected areas (MPAs) have been designated in many places in the world. However, marine areas have been traditionally managed on a case-by-case, sector-by-sector basis, ignoring the interdependent nature of ecosystem components. Conventional sectoral management and piecemeal governance are considered less and less appropriate in pursuit of sustainable development, as the interaction among activities and the cumulative impacts of these activities are ignored (Foley et al., 2010; Halpern et al., 2008b). Thinking in prescribed administrative units also makes it more difficult to measure and counter potentially cumulative effects of sea uses or to tap previously unexplored synergies. There is an urgent need for a fundamental shift in the way we manage our oceans and coasts towards a holistic and integrated approach to management.
Ecosystem-based marine spatial management (EB-MSM) is an emerging paradigm of ocean management, which is being promoted by institutions worldwide as the best way to ensure the sustainability of marine ecosystems and their services to humans, and to deal with conflicts among various users of the seas. In recent years much has been written on the scientific concepts and principles of EB-MSM (Levin et al., 2009) and the various difficulties in implementing those (Arkema et al., 2006; Tallis et al., 2010). A comprehensive review by Curtin and Prellezo (2010) aimed to describe what is meant by an ecosystem based management and how it has been implemented, while other reviews tackled specific questions such as the methods for defining future scenarios in EBMSM (Francis et al., 2011). However, an extensive review on the tools supporting the implementation of EB-MSM is still pending. A sound knowledge base on the tools in the context of EB-MSM is crucial to move from a more conceptual discussion to a practical implementation. With this review we address this gap and also try to derive a more comprehensive insight about the nature and scope of EB-MSM and the related challenges. The main questions we strived to answer are: What is EB-MSM and what are its benefits? What are the recent developments in EB-MSM and the related objectives? What are the most important tools for EB-MSM and their essential characteristics? How critical issues for marine management such as climate change and geohazard risks can be effectively tackled within EB-MSM frameworks? What are the gaps and research needs for effective EB-MSM?

\section{The general concept of EB-MSM}

Ecosystem based management is an environmental management approach that recognizes the full array of interactions within a marine ecosystem, including humans, rather than considering single issues, species, or ecosystem services in isolation. The goal of ecosystem based marine management is to maintain marine ecosystems in a healthy, productive and resilient condition so that they can sustain human uses of the ocean and provide the goods and services humans want and need (McLeod et al., 2005). Foley et al. (2010) stated that the future of the ocean depends on successful, immediate implementation of a comprehensive governance framework that moves away from a sectoral management approach to an integrated approach. Such an approach would (1) balance the increasing number, diversity and intensity of human activities with the ocean's ability to provide ecosystem services; (2) incorporate appropriate ecological, economic, social and cultural 
perspectives; and (3) support management that is coordinated at the scale of ecosystems as well as political jurisdictions. Although there are ecosystem approaches to marine management that are not necessarily place-based, in most cases marine ecosystems are fixed in space. Hence, the spatial component is inherently critical in the concept of ecosystem-based management, which justifies the notion of EB-MSM.

The successful development and implementation of EB-MSM requires the use of best available science. New tools, such as geospatial analysis, remote sensing, molecular techniques, telemetry, modelling, and quantitative analysis to understand the spatial and temporal dynamics of marine organisms and ecosystems in relation to environmental variation have been developed. These new tools have broadened the understanding of the linkages between marine habitats and population dynamics, and between spatiotemporal dynamics and the functioning of marine food webs (Crowder and Norse, 2008). Furthermore, the way forward to support EB-MSM is by data integration across traditional disciplines at appropriate scales: i.e. building upon existing information collected for a variety of specific purposes and providing a framework to combine these data (Carollo et al., 2009). In addition to making use of the best science available, managers have to continuously learn and adapt management whenever new information is available.

An in-depth review of the application of the ecosystem approach, carried out by the Convention on Biological Diversity, revealed that several barriers are preventing the actual implementation of EB-MSM (Douvere and Ehler, 2008). The ecosystem approach is still more of a concept which is widely discussed at scientific fora, but with very limited examples of actual practise, mainly due to the difficulties met in coupling environmental safety and sustainable use of resources with stakeholder's needs and expectations. There are still major science and knowledge gaps in applying the ecosystem approach to management, related to our limited understanding of the dynamics and resilience of populations, biological communities and ecosystems, the dynamics of human uses of marine ecosystems and their cumulative impacts on the marine environment, the effectiveness of management and governance systems, and how to conduct fully integrated assessments across environmental, economic, and social dimensions of marine systems (Rice et al., 2010).

It is important to recognise that EB-MSM is a decision support mechanism. It does represent an important advance from reductionist notions of a single "scientific" optimal solution to marine management problems. We are however still left with the question of how to implement EB-MSM approaches. If it is seen as another 'command and control' process telling stakeholders what they should do there is a danger of failure. In many parts of the world traditional self-governance approaches to managing marine resources still exist. Integrating EB-MSM approaches with traditional systems will be a particular challenge (e.g., Cinner and Aswani, 2007; Ruddle and Hickey, 2008). Even in societies with formal regulatory planning institutions the collaborative dimension is still important (Armitage et al., 2009; Kerr et al., 2006). While it may be naive to think that all stakeholders can reach consensus on all decisions, it is important that there is consensus and consensibility regarding the decision-making processes being employed (Seabright, 1993).

\section{Legislation and operational objectives}

\subsection{From high-level goals to operational objectives}

Planning and management are driven either implicitly or explicitly by goals. Goals are high-level outcomes that a planning process or management aims to achieve through the implementation of measures. High-level goals are a crucial part of any management and are based on societal or cultural values. In contrast, descriptors, criteria, and indicators that are associated to a high-level goal are developed in the scientific domain (Moilanen et al., 2009 and references therein). To achieve high-level goals, managers should translate them into clear, measurable, short-term goals before any specific targets, limits and measures can be elaborated. Such goals are termed operational objectives (Fig. 1) and their definition is crucial for the success of a management plan.

In recent years the formulation of operational objectives and operational deliveries has been proposed in the wider context of an ecosystem based approach to marine management. For example, Rogers et al. (2007) described a hierarchical framework that incorporates the marine objectives and delivery statements of ecological, social and economic sectors and outlined the relationship between high-level goals and operational objectives. Experience from the implementation of an ecosystem approach to fisheries has also shown the importance of translating high-level policy strategies and goals into operational objectives. Such objectives should be clarified in relation to management structure, process, and measures, hence rationalising and bringing transparency in the implementation path between high-level policies and on-the-ground fishing operations (Garcia et al., 2003).

To be effective and useful for evaluating the management performance of spatially managed areas, operational objectives need to be SMART (sensu ICES, 2005): (1) Specific: objectives should clearly specify the state to be achieved, and be interpreted unambiguously by all stakeholders; (2) Measurable: objectives should relate to measurable properties of ecosystems and human societies, so that indicators and reference points can be developed to measure progress towards the objective; (3) Achievable: it should be possible to achieve all objectives, which should not conflict; (4) Realistic: it should be feasible to implement the objectives using the resources (research, monitoring, assessment and enforcement tools) available to managers and stakeholders; and (5) Time bound: there should be a clearly defined time scale for meeting objectives.

\subsection{International policies and objectives}

A number of overarching international conventions, treaties and laws recognise the need to consider human pressures in the marine environment through an integrated, ecosystem approach to management of maritime activities. Some of these mainly address the coastal zone, as has been the common practise until recent years, when focus expanded to include the open sea and the high seas. The most relevant international legislation and policies to EB-MSM are the United Nations Convention on the Law of the Sea (UNCLOS), the Convention on Biological Diversity (CBD), the United Nations Agenda 21, and the FAO Code of Conduct for Fisheries.

UNCLOS is an international agreement in force since 1994. It is a comprehensive regime of law and order for the world's oceans and seas that governs all aspects of ocean space such as delimitation, environmental control, marine scientific research, economic and commercial activities, transfer of technology and the settlement of disputes relating to ocean matters. UNCLOS is also the mechanism through which the designation of exclusive economic zones is coordinated. UNCLOS includes a number of other provisions concerning the marine environment in relation to marine pollution, alien species, global and regional cooperation, and highly migratory species.

CBD, established in 1992, is the most comprehensive and significant international instrument addressing the threats to biodiversity, as well as protecting, understanding and using natural resources sustainably. It requires all member nations to establish 
a system of protected areas and develop guidelines for the selection, establishment and management of these areas. The strategic plan of the CBD laid down the target of achieving a significant reduction in the current rate of biodiversity loss by 2010 at the global, regional and national level. This target was confirmed in the plan of implementation adopted at the World Summit on Sustainable Development in Johannesburg in 2002. However, this target was not achieved and in November 2010, in Nagoya, new targets were agreed and one new hard law protocol was finalised (Harrop, 2011). CBD has three high-level goals: (1) the conservation of biological diversity; (2) the sustainable use of its components; and (3) the fair and equitable sharing of benefits arising from the use of genetic resources. These objectives are to be met through the implementation of a number of measures including the development of national strategies, the integration of biodiversity considerations into sectoral and cross-sectoral plans, the establishment of monitoring programmes, and extensive measures for in-situ and ex-situ conservation. CBD prescribes the ecosystem approach in achieving these objectives and states that implementation must be consistent with UNCLOS.

The Agenda 21 programme was introduced in 1992 during the United Nations Conference on Environment and Development. Its full implementation was affirmed during the World Summit on
Sustainable Development in 2002, during which States also committed themselves to promote the sustainable development of marine ecosystems through the application of the ecosystem approach by 2010 . Agenda 21 promotes integrated, multisectoral, coastal and ocean management at the national level through a set of concrete objectives, some of which relate directly to spatially managed marine areas: to promote compatibility and a balance of uses by integrating policy and decision-making process with all involved sectors; to identify existing and projected uses of coastal areas and their interactions; and to apply preventive and precautionary approaches in project planning and implementation, including prior assessment and systematic observation of the impacts of major projects.

The FAO Code of Conduct for Responsible Fisheries (FAO, 1995) provides principles and standards applicable to the conservation, management and development of all fisheries. It also covers the capture, processing and trade of fish and fishery products, fishing operations, aquaculture, fisheries research and the integration of fisheries into coastal zone management. The Code of Conduct for Responsible Fisheries is supplemented by the FAO Guideline on the Precautionary Approach (FAO, 1996). This Guideline is a coherent framework for managers, based on clear identification of management objectives and the use of indicators and reference
Example 1

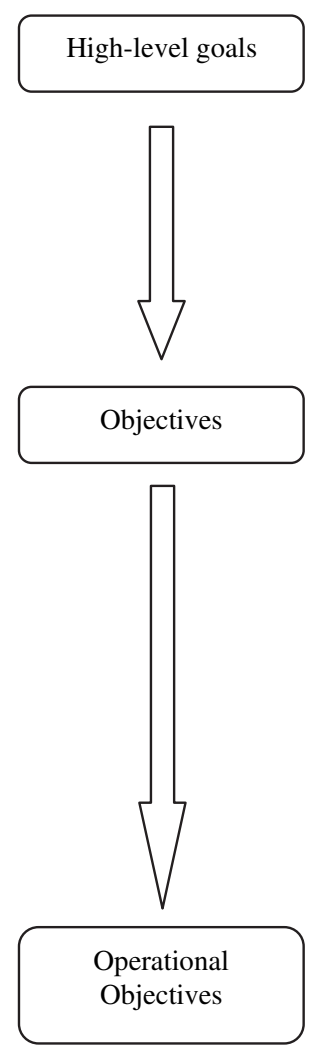

Example 2

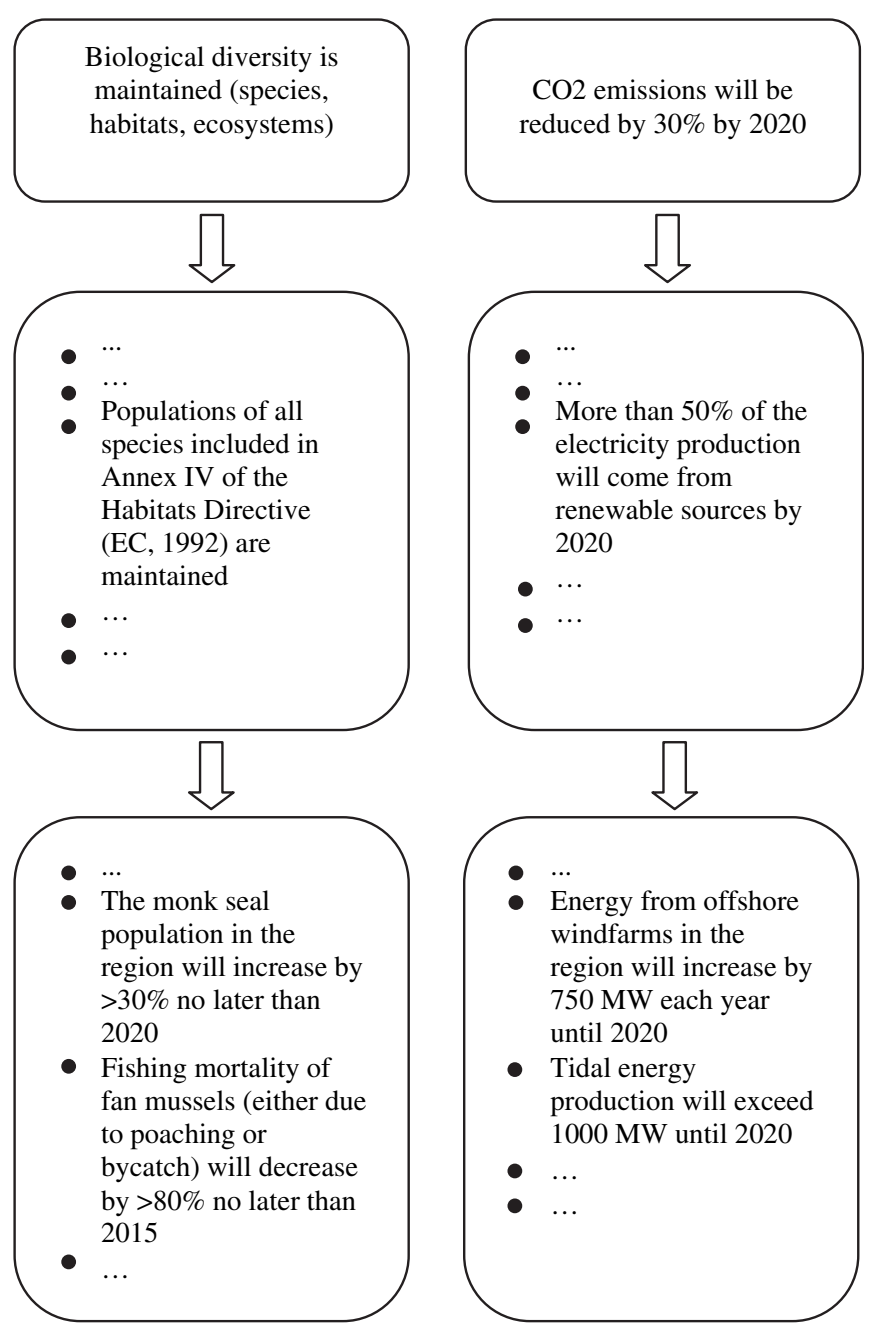

Fig. 1. From high-level goals to operational objectives: visualisation and examples. 
points to evaluate the stock status and fishery performance, taking into account uncertainty in all phases of management process.

Despite the effort made so far, a number of institutional and legal challenges exist for succeeding to reach the high-level goals set by international policies. In particular, beyond areas of national jurisdiction no adequate mechanisms exist yet for the effective management of the seas, surveillance, and enforcement of management measures. There are several legal issues that complicate the spatial management of international areas, including specific interests, rights and competence of various entities, such as the rights of coastal States over their extended continental shelf, and the potentially conflicting competences of global organisations (e.g. the International Seabed Authority) and regional environmental or fisheries organisations (Salpin and Germani, 2010).

\subsection{Regional objectives: the European example}

Regional and national legislation is decisive in shaping the terms and guidelines for EB-MSM, usually in conformity to international high-level policies. For example, in the European Union a suite of fundamental policies and directives have set a number of goals and objectives that largely define EB-MSM. These include the Habitats Directive (EC, 1992), the Birds Directive (EC, 2009), the Water Framework Directive (WFD; EC, 2000), the Strategic Environmental Assessment Directive (SEA Directive; EC, 2001), the Common Fisheries Policy (CFP), and the Marine Strategy Framework Directive (MSFD; EC, 2008b) (for more details see Suppl. 1).

The Birds and the Habitats Directives are two major drivers of establishment of protected areas in EU waters. Both directives serve as a legally binding basis for the establishment of a set of terrestrial and marine protected areas, collectively known as Natura 2000 network. The WFD is a legislative framework that rationalises and updates existing water legislation by setting common EU wide objectives for water bodies, including coastal waters. It introduces an integrated and coordinated approach to water management in Europe. The SEA Directive requires certain public plans and programmes to undergo an environmental assessment to provide for a high level of protection of the environment and to promote sustainable development. The CFP defines a policy framework to ensure sustainable exploitation of living aquatic resources and includes measures to protect sensitive species and habitats from the impacts of fishing. The MSFD is the environmental pillar of the future maritime policy for EU and aims to achieve 'Good Environmental Status' (GES) in EU marine areas by the year 2020 at the latest. Annex 1 of the MSFD provides 11 qualitative descriptors of GES, which can be considered as the basis for high-level goals (Table 1). The descriptors of GES are explicitly defined as being qualitative; to become operational quantification is required. Task groups have been organised by ICES and JRC to assist with the development of these criteria and methodological standards (see Cardoso et al., 2010; EC, 2010; Table 1).

\section{Monitoring, evaluation and adaptive management}

In spite of the efforts in ecological management, mismanagement of biological resources has been common and well publicized (Chadwick, 1996; Gallangher and Carpenter, 1997; Parfit, 1995). Although economical and political factors are major contributors to these failures (Holmes, 1994) the limits of our ability to predict the response of ecosystems to human interventions have certainly played an important role, as can be seen in cases in which management disasters can be traced to seriously flawed assessments and forecasts (Walters and Maguire, 1996). To get the most out of human interventions, a plan is needed that: (1) recognizes the uncertainty; (2) contemplates monitoring system responses to interventions; and (3) anticipates that future management interventions will be modified as we gather more information and learn about the behaviour of the system.

Table 1

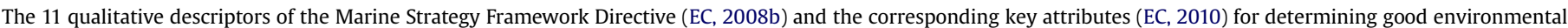
status.

\begin{tabular}{|c|c|}
\hline Qualitative descriptors & Key attributes \\
\hline \multirow{3}{*}{$\begin{array}{l}\text { Biological diversity is maintained. The quality and occurrence of habitats and the } \\
\text { distribution and abundance of species are in line with prevailing } \\
\text { physiographic, geographic and climatic conditions }\end{array}$} & Species level (species distribution, population size, population condition) \\
\hline & Habitat level (habitat distribution, extent, condition) \\
\hline & Ecosystem level (Ecosystem structure) \\
\hline \multirow{2}{*}{$\begin{array}{l}\text { Non-indigenous species (NIS) introduced by human activities are at levels that } \\
\text { do not adversely alter the ecosystems }\end{array}$} & Abundance and state characterisation \\
\hline & Environmental impact \\
\hline \multirow{3}{*}{$\begin{array}{l}\text { Populations of all commercially exploited fish and shellfish are within safe } \\
\text { biological limits, exhibiting a population age and size distribution that is } \\
\text { indicative of a healthy stock }\end{array}$} & Level of pressure of the fishing activity \\
\hline & Reproductive capacity of the stock \\
\hline & Population age and size distribution \\
\hline \multirow{3}{*}{$\begin{array}{l}\text { All elements of the marine food webs, to the extent that they are known, occur } \\
\text { at normal abundance and diversity and levels capable of ensuring the } \\
\text { long-term abundance of the species and the retention of their full } \\
\text { reproductive capacity }\end{array}$} & Productivity \\
\hline & Proportion of selected species as the top of food webs \\
\hline & Abundance/distribution of key trophic groups/species \\
\hline \multirow{3}{*}{$\begin{array}{l}\text { Human-induced eutrophication is minimised, especially adverse effects thereof, } \\
\text { such as losses in biodiversity, ecosystem degradation, harmful algae blooms } \\
\text { and oxygen deficiency in bottom waters }\end{array}$} & Nutrient levels \\
\hline & Direct effects of nutrient enrichment \\
\hline & Indirect effects of nutrient enrichment \\
\hline \multirow{2}{*}{$\begin{array}{l}\text { Sea-floor integrity is at a level that ensures that the structure and functions of } \\
\text { the ecosystems are safeguarded and benthic ecosystems, in particular, are } \\
\text { not adversely affected }\end{array}$} & Physical damage \\
\hline & Condition of benthic community \\
\hline \multirow{2}{*}{$\begin{array}{l}\text { Permanent alteration of hydrographical conditions does not adversely affect } \\
\text { marine ecosystems }\end{array}$} & Spatial characterization of permanent alterations \\
\hline & Impact of permanent hydrological changes \\
\hline \multirow[t]{2}{*}{ Concentrations of contaminants are at levels not giving rise to pollution effects } & Concentration of contaminants \\
\hline & Effects of contaminants \\
\hline $\begin{array}{l}\text { Contaminants in fish and other seafood for human consumption do not exceed } \\
\text { levels established by Community legislation or other relevant standards }\end{array}$ & Levels, number and frequency of contaminants \\
\hline $\begin{array}{l}\text { Properties and quantities of marine litter do not cause harm to the coastal and } \\
\text { marine environment }\end{array}$ & $\begin{array}{l}\text { Characteristics of litter in the marine and coastal environment } \\
\text { Impacts of litter on marine life }\end{array}$ \\
\hline $\begin{array}{l}\text { Introduction of energy, including underwater noise, is at levels that do not } \\
\text { adversely affect the marine environment }\end{array}$ & $\begin{array}{l}\text { Distribution in time and place of loud, low and mid frequency impulsive sounds } \\
\text { Continuous low frequency sound }\end{array}$ \\
\hline
\end{tabular}


An increasing number of scientists and resource managers recognise that successful marine management approaches, including EB-MSM, cannot occur without effective monitoring, evaluation and adaptation (Day, 2008). Although originating already in the 1970's, adaptive management is now a buzzword, commonly confused with an ad hoc trial and error approach to management as in 'action first, science later' (Parma et al., 1998). However, adaptive management should be noted as managing according to a plan by which decisions are made and modified as a function of what is known and learned about the system, including information about the effect of previous management actions (Ludwig et al., 1993; Parma et al., 1998). Irrespective of whether a change in marine management results from new data, 'in-the-field' experience, or as a result of external circumstances, EB-MSM practises must be periodically reviewed and updated where appropriate. Adaptive management enables managers to be flexible and to expect, and deal with, the unexpected (Day, 2008). It could be either passive or active and it needs to be distinguished from the precautionary approach (Table 2).

Because both natural systems and management approaches are never static, continuous and iterative monitoring, evaluation, reporting and adaptive management are fundamental components for effective marine management. The challenge is how to develop realistic operational objectives and indicators against which effectiveness can be measured. This can be quite complicated as the focus of marine planning and management strategies are not only single species but also habitats and whole ecosystems. In addition to this, it may also be relevant to set multiple objectives taking into account interactions between ecological, economical and societal factors. This makes the development of operational objectives and the associated criteria and indicators even more complicated.

In addition to monitoring the state of the environment, monitoring management performance is also an important task in order to know if implemented management measures are efficient, effective and equitable (Douvere and Ehler, 2011). The most important reasons for evaluating management performance and effectiveness in marine ecosystems are to demonstrate the extent to which the objectives of marine planning and management have been achieved, to provide evidence-based feedback about what is working and what is not, and to learn more about interactions between ecological components and management efforts.

In recent years, governments have placed growing emphasis on outcome-based (rather than activity-based) performance reporting, which includes measures of performance in achieving objectives or targets. Jones (2000) provided one example of an evaluative management framework comprising seven key steps (Fig. 2a). Pomeroy et al. (2005) developed a step-by-step guide to managers and practitioners for evaluating effectiveness of MPA management (Fig. 2b) based on a set of biophysical, socioeconomic and governance goals and 42 corresponding indicators. As there has been a history of adapting methods and concepts from MPA experiences to the wider MSP and ecosystem based management context, such evaluations may provide a good basis for a wider framework of EB-MSM.

To evaluate the effectiveness of a management plan, a range of ecological, socioeconomic and governance indicators that measure the status of attributes related to operational objectives need to be developed (Belfiore et al., 2006; Douvere and Ehler, 2011; Pomeroy et al., 2004, 2005). Indicators are quantitative or qualitative statements or parameters that simplify information related to existing situations and measure trends over time. Indicators need to have a number of characteristics to be good and reliable measures of ecosystem status and management performance. They should be readily measurable on the time scales needed to support management, cost effective, concrete, interpretable, grounded on scientific theory, sensitive, responsive, and specific (Belfiore et al., 2006). Indicators, together with carefully chosen thresholds, can be used to define performance measures to assess the achievement of management objectives and to define decision rules for adaptive management strategies to respond to impacts (Fulton et al., 2005; Sainsbury et al., 2000). Moreover, indicators could also reflect aspects of concern to stakeholders and therefore their meaning should be understood by as wide a range of stakeholders as possible (Douvere and Ehler, 2011). Many ecological, socioeconomic and governance indicators have been developed that fit the needs for evaluation of a great variety of operational objectives (Table 3 ).

Evidence-based feedback (Day, 2008) is crucial to the achievement of the objectives of any adaptive management framework (Blæsbjerg et al., 2009; Ekebom et al., 2008; Foley et al., 2010; Grafton and Kompas, 2005; Pomeroy et al., 2005; Walters and Hilborn, 1976), as it provides important output from a past process that must inform and influence current or future processes. Considering that most evaluations of spatially managed areas in the marine environment focus on biophysical aspects and that these evaluations rarely involve management staff (Ehler and Douvere, 2009), it is important that evaluations are formulated and communicated in a way that ensures that feedback re-enters the adaptive management cycle as effectively as possible to improve the likelihood of successful management in future.

Table 2

Definitions and characteristics of Adaptive Management and the Precautionary Approach. Modified after Parma et al. (1998).

\begin{tabular}{|c|c|c|c|c|}
\hline & & & Definition & Characteristics \\
\hline $\begin{array}{l}\text { Precautionary } \\
\text { approach }\end{array}$ & & & $\begin{array}{l}\text { We should not proceed with ecological } \\
\text { intervention unless we are reasonably } \\
\text { sure that this will not cause a } \\
\text { significant long-term loss of productivity } \\
\text { or a significant long-term impact on the } \\
\text { environment (FAO, 1995) }\end{array}$ & $\begin{array}{l}\text { - experimental management must be } \\
\text { conservative } \\
\text { - must gain information first and then } \\
\text { explore the system }\end{array}$ \\
\hline $\begin{array}{l}\text { Adaptive } \\
\text { management }\end{array}$ & $\begin{array}{l}\text { Whenever a strategy is actively or } \\
\text { passively adaptive, the system } \\
\text { responses are monitored, effects } \\
\text { of past actions are evaluated, and } \\
\text { management is able to respond } \\
\text { in an effective and timely } \\
\text { manner to what is learned. }\end{array}$ & $\begin{array}{l}\text { Passive } \\
\text { Active }\end{array}$ & $\begin{array}{l}\text { When policies are adapted in response } \\
\text { to new information, but learning is not } \\
\text { incorporated as a management goal } \\
\text { (Parma et al., 1998) } \\
\text { As in experiments, in management the } \\
\text { information value of alternative } \\
\text { candidate actions is considered in } \\
\text { evaluating choices (Parma et al., 1998) }\end{array}$ & $\begin{array}{l}\text { - possible high costs; we don't know how much } \\
\text { we losse due to the component 'don't know } \\
\text { enough detail' } \\
\text { - misses the opportunity to learn fast } \\
\text { - ignore future learning } \\
\text { - probable great costs because the environment } \\
\text { is manipulated as a whole } \\
\text { - short-term negative effects perceivable } \\
\text { - Benefits expected from learning must } \\
\text { overcompensate the short-term costs of } \\
\text { implementing experiments. }\end{array}$ \\
\hline
\end{tabular}


a

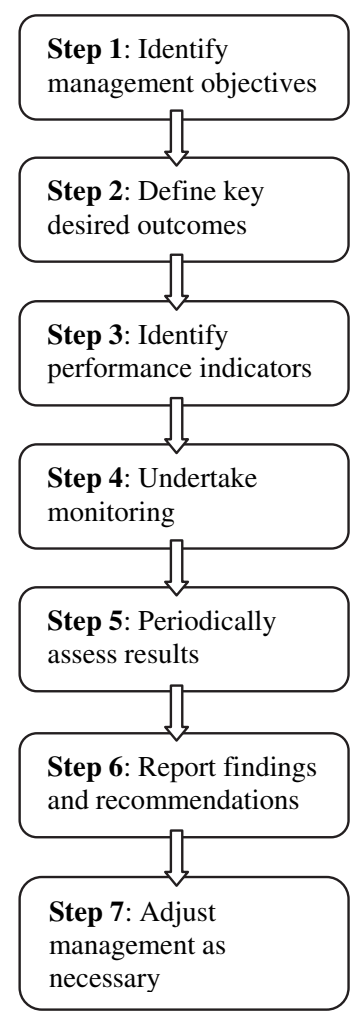

b

Step 1: Select your indicators

1.1 Identify MPA goals and objectives

1.2 Match relevant indicators to MPA goals and objectives

1.3 Review and prioritize the indicators identified

1.4 Identify how the selected indicators relate to one another

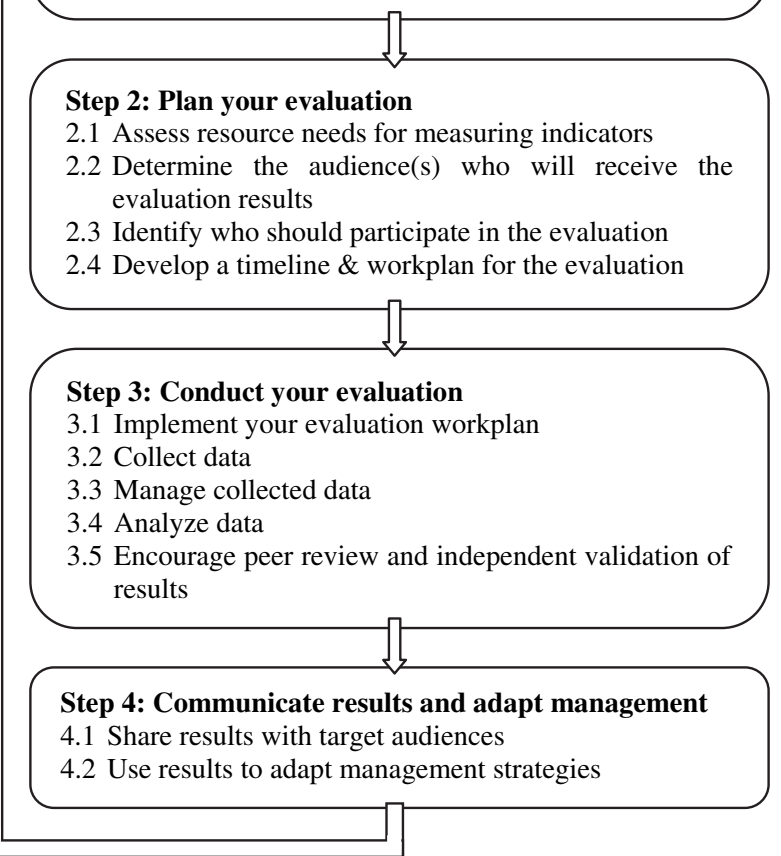

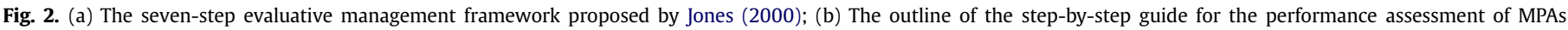
proposed by Pomeroy et al. (2004, 2005).

Feedback from evaluations may also facilitate in the ongoing identification of research needed to inform management in relation to knowledge gaps (Ehler and Douvere, 2009). However, to ensure that feedback is understood outside e.g. the scientific community all of the above examples require effective communication strategies (Ehler and Douvere, 2009; Pomeroy et al., 2005; Pomeroy and Douvere, 2008).

Adaptive management is a type of experimental management and, as such, it has its limitations. This may explain why it has not been more commonly implemented. The major limitations are constraints in policies and legislation, difficulties in monitoring populations and their responses to interventions, lags in system responses, and limits in our ability to depict all possible states of nature (Parma et al., 1998). Adaptive management also forces us to evaluate the effects of past actions as part of the management plan (Mangel et al., 1996), and implies that management is able to respond effectively. Finally, adaptive management is based on the recognition that our actions in the future will change as new information is obtained (Platt, 1964).

\section{Marine spatial planning and ocean zoning}

Marine Spatial Planning (MSP) is an essential tool for EB-MSM (Ehler, 2008; Halpern et al., 2008b). It has emerged as a means of

Table 3

Publications developing ecological, socioeconomic and governance indicators for the evaluation of spatially managed marine areas.

\begin{tabular}{|c|c|}
\hline Publication & Description \\
\hline $\begin{array}{l}\text { Pomeroy et al., 2004, } 2005 \\
\text { (IUCN Guide book) }\end{array}$ & $\begin{array}{l}\text { Step-by-step guidance is provided to managers and other practitioners in selecting relevant biophysical, socioeconomic, } \\
\text { and governance indicators for the evaluation of MPAs. A list of } 42 \text { MPA-relevant indicators is provided (10 biophysical, } \\
16 \text { socioeconomic, } 16 \text { governance), associated with general goals and objectives. }\end{array}$ \\
\hline Belfiore et al., 2006 (UNESCO handbook) & $\begin{array}{l}\text { It provides a step-by-step guide to help users in developing, selecting and applying a common set of governance, } \\
\text { ecological and socioeconomic indicators to measure, evaluate and report on the progress and outcomes of Integrated } \\
\text { Coastal and Ocean Management interventions. It includes a detailed description of } 37 \text { indicators ( } 9 \text { ecological, } 13 \\
\text { socioeconomic, and } 15 \text { governance) }\end{array}$ \\
\hline Ojeda-Martínez et al., 2009 & $\begin{array}{l}\text { A general conceptual framework for the management of marine protected areas (MPAs) was developed. The } \\
\text { driver-pressure-state-impacts-response (DPSIR) framework was used to determine the elements affecting MPAs. } \\
\text { The developed evaluation framework helped to select an appropriate suite of } 149 \text { indicators to support an ecosystem } \\
\text { approach, an assessment of the MPAs functioning and policy decisions. }\end{array}$ \\
\hline Cardoso et al., 2010 & $\begin{array}{l}\text { The Marine Strategy Framework Directive proposes } 11 \text { descriptors of the GES that cover the most common components } \\
\text { relevant for likely operational objectives for MSP. Several task groups developed a suit of indicators for those descriptors, } \\
\text { which are collectively described in this report. }\end{array}$ \\
\hline
\end{tabular}


resolving inter-sectoral and cross-border conflicts over maritime space and has been therefore defined as a way of improving decision making and delivering an ecosystem-based approach to managing human activities in the marine environment (Douvere, 2010). However, MSP concepts are still open to very diverse interpretations (Gilliland and Laffoley, 2008).

MSP is a public process of analysing and allocating the spatial and temporal distribution of human activities in marine areas to achieve ecological, economic, and social objectives that have usually been specified through a political process (Ehler and Douvere, 2007). Foley et al. (2010) defined ecosystem based MSP as an integrated planning framework that informs the spatial distribution of activities in and on the ocean in order to support current and future uses of ocean ecosystems and maintain the delivery of valuable ecosystem services for future generations in a way that meets ecological, economic and social objectives.

The concept of MSP was stimulated by international and national interests in developing marine protected areas (MPAs). More recent attention has been placed on planning and managing multiple uses of maritime space, particularly in areas where use conflicts are already well known and specified. Ecosystembased MSP aims to bridge the gap between science and practise and help fill the current need of both governments and nongovernmental organisations for more practical tools that move forward the implementation of ecosystem-based management in marine places (Douvere, 2008). The MSP decision-making process should be based on ecological principles such as native species diversity, habitat diversity and heterogeneity, key species, and connectivity, with clearly defined targets for those ecological attributes (Foley et al., 2010). In addition, the associated levels of uncertainty must be taken into account in the MSP planning process. Recently a guide of ten practical steps on how to make MSP operational was launched by UNESCO, based on international examples of MSP at different stages of development from all around the globe (Ehler and Douvere, 2009).

An increasing number of countries are using MSP to achieve both sustainable use and biodiversity conservation in ocean and coastal areas. While some countries have specific legislation for MSP (e.g., the UK has the Marine and Coastal Access Act), most do not and certain countries use existing authorities - including environmental legislation (like Belgium) or biodiversity legislation (like Australia) - or existing land-use planning legislation that is extended to the sea (The Netherlands and Germany) as a basis of authority for MSP (Douvere, 2010). A review of MSP initiatives can be found in Douvere (2010) and in UNESCO's MSP Initiative (www. unesco-ioc-marinesp.be/msp_around_the_world).

In Europe most ecosystem-based sea use management and MSP initiatives are driven by international and European legislation (Douvere and Ehler, 2008). Various legal and policy documents have been introduced by the European Commission to implement MSP, one of which is the Green Paper on Maritime Policy which identifies MSP as a key tool for the management of a growing and increasingly competing maritime economy, while at the same time safeguarding marine biodiversity (EC, 2006). The recent EU Communication on MSP (EC, 2008a) considers it as a key instrument for the application of the European Integrated Maritime Policy and lays out some guiding principles encouraging the development of a common approach among member states. EU research programmes support multidisciplinary research to further develop MSP, e.g. the MESMA project (www.mesma.org) is focussing on monitoring and evaluation of spatially managed areas and will develop innovative methods and integrated marine planning strategies (Ter Hofstede et al., 2010).

Stakeholder involvement is an important component of MSP as it reduces conflicts among users (Ehler, 2008). The stakeholders that are involved in the process must reflect the existing complexity in reality (Pomeroy and Douvere, 2008). Moreover, stakeholders should be involved in developing the overall MSP framework and planning production process, rather than only being consulted on a final actual plan (Gilliland and Laffoley, 2008).

Currently, most MSP initiatives are confined within national boundaries and only take into account local habitats and ecosystems (Maes, 2008). But various uses such as shipping, fisheries and pipelines may have impacts across boundaries and therefore MSP has to be implemented on a regional and international level (Douvere and Ehler, 2008). Ultimately, national MSP initiatives should further develop into cross-border and regional marine spatial plans to fully implement a sustainable EB-MSM.

Ocean zoning $(\mathrm{OZ})$ is a set of regulatory measures used to implement marine spatial plans and it is considered as one tool for EB-MSM (Ehler and Douvere, 2007). OZ partitions a region into zones that are designed to allow or prohibit certain activities, with the intent to maintain the provision of an overall set of ecosystem services provided by the overall zoned area; such a zoning process needs to pay particular attention to the consequences of allowing multiple conflicting activities to occur within the same location (Halpern et al., 2008b). Zoning in which environmental protection is harmonized with uses of the sea is likely the most effective approach to mitigate and possibly reverse extensive and increasing human impacts on marine and coastal ecosystems (Agardy, 2009). Comprehensive $\mathrm{OZ}$ may not only reduce conflicts through the creation of use-priority areas but also act as a catalyst for users within zones to coordinate their activities, especially with the creation of dominant-use zones (Sanchirico et al., 2010).

Whereas terrestrial zoning is usually operated at small spatial scales, within the remit of municipal planning authorities, OZ often must recognize the wide linkages across marine and coastal ecosystems. It must also systematically address uses of, and impacts on, the marine environment at a regional scale, taking into account transboundary issues and international legislation. Lack of property rights in the ocean can hinder efforts to apply the land-based principles of zoning to the marine environment. However, zoning of communal or common property such as marine space and resources is possible by amending legislation towards use rights. Experience in the largest zoned area of the world ocean, the Great Barrier Reef Marine Park, showed that a simple zones classification was crucial for public acceptance (Day, 2002).

There are many tools for ocean zoning under development. The most popular one is "Marxan with Zones" (Watts et al., 2009), which helps creating alternative zoning configurations that maximize the achievement of social, economic, and ecological objectives while minimising the total social, economic, and ecological cost. Another emerging analytical method useful for ocean zoning focuses on mapping of cumulative impacts of different suites of human activities on the ocean. The overall impact of all human activities on ocean condition can be assessed and particular activities can be included or excluded from consideration to determine what suite of activities can best meet objectives for a given zone (see e.g. Ban et al., 2010; Halpern et al., 2008a; Stelzenmüller et al., 2010).

\section{MPAs within the EB-MSM context}

The IUCN definition of MPA (Dudley, 2008) is "a clearly defined geographical space, recognized, dedicated and managed, through legal or other effective means, to achieve the long-term conservation of nature with associated ecosystem services and cultural values". The current global movement towards EB-MSM has put a spotlight on the interlinkages between MPAs and EB-MSM. Stakeholders often assume that MPAs and EB-MSM or MSP are 
interchangeable concepts, however this is not the case (e.g. Blæsbjerg et al., 2009). EB-MSM has a broader remit and provides an overall spatial framework for ecosystem based management of maritime activities, whereas MPAs are one of the management tools within that planning framework, i.e. providing a means for emphasised protection of features and processes in a given ecosystem that merit site specific management measures. There are often fewer economic sectors involved in MPAs, and MPA zoning restrictions mainly target fishing and recreational use. Both MPAs and MSP are recognised as area-based tools for implementing the ecosystem approach in managing the marine environment. Admittedly, both tools are insufficient in achieving the all-encompassing EB-MSM goals if applied on their own (Douvere, 2008; Halpern et al., 2010). Such view is based on the fact that many stressors to marine ecosystems, such as land-based pollution and climate change, are not spatial in nature (Halpern et al., 2010).

Many studies on the ecological effects of MPAs highlight that they provide multiple benefits to the ecosystem (Agardy, 1994; García-Charton et al., 2008; Sobel and Dahlgren, 2004; Zabala, 1999). The need for ecologically coherent MPA networks that enhance cumulative interactions and effectiveness of conservation over a wider geographical scale has been recognized (Agardy, 2005; EC, 2008b; Fernandes et al., 2005; Gaines et al., 2010; IUCN-WCPA, 2008; Roberts, 1997; Roberts et al., 2003; Sala et al., 2002). A functioning, ecologically coherent network of MPAs should interact with the surrounding environment and other MPAs. However, such a scheme is dependent on appropriate management to support good ecosystem health and functioning both within and outside the networks of MPAs. EB-MSM is the broader context that gratifies the need for such integrated management and protection in the entire marine area.

There are many examples of MPAs failing to accomplish their stated targets, mainly because of wrong design, poor enforcement, and set up or unrealistic expectations (Alder, 1996; Guidetti et al., 2008; Jameson et al., 2002; Kelleher et al., 1995; McClanahan, 1999). The effectiveness of MPAs for sustaining fish stock yields has been challenged by many authors arguing that conventional fisheries management approaches are more effective and MPAs might lead to reduced fish stock production due to densitydependent factors and reallocation of fishing effort (Kaiser, 2005; Norse et al., 2003; Shipp, 2003; Steele and Beet, 2003). However putting fisheries management in the wider context of EB-MSM will potentially resolve such issues.

In the past decades fisheries stakeholders and nature conservation proponents have been the main drivers of the general debate over MPAs. Meanwhile, a number of other sectors have made an ever-growing number of claims in marine areas for e.g. aggregate extraction, pipelines and wind farms. In particular, the designation of wind farm sites and the construction of turbines at sea, driven by the current demand for clean energy, have had a highly significant effect on the political landscape surrounding sea use. Increasingly, conservationists and fisheries stakeholders can be found on the same side of the fence in public debates over impacts of e.g. construction plans or importance of specific marine sites. This reveals that marine habitats and species can no longer be considered in isolation in fisheries management and nature conservation regimes. In order to optimize space allocation and to add sufficient weight to claims, these sectors will likely need to identify marine areas that represent essential sites for both sensitive species and habitats as well as for living resource management. Overlaps in geography or within sectoral objectives are likely to facilitate the discovery of mutual opportunities and benefits that are important to consider in relation to MPA development within wider EB-MSM frameworks.

\section{Socio-economic valuation of spatially managed areas}

\subsection{Values and utility}

When it comes to management interventions, the cost and benefits have to be evaluated. The assignment of values to biophysical features of the marine environment allows the assessment of alternatives. Society clearly values features of the marine environment: economic resources, the provision of environmental services, and marine biodiversity. EB-MSM, indeed any management, will potentially alter the distribution of these values. Economic activities in marine environments almost inevitably create spatial externalities, in the presence of which Pareto-efficiency is hardly reachable. The general assumption is that good management should produce a net gain. This is the basis of cost benefit analysis (CBA).

Nunes and van den Bergh (2001) suggest that marine environmental value is the sum of all utility experienced by individuals. This worldview is anthropocentric, rejecting intrinsic values or ethical considerations sometimes cited as management criteria (Dobson, 1996; Naess, 1985). Derous et al. (2007a, 2007b) argue that intrinsic biological values should underpin MPA selection, i.e. rarity, aggregation, fitness, naturalness, and proportional importance. For conventional economics these values are not "intrinsic" but simply the values of conservation biologists.

The concept of Total Economic Value (TEV) is now widely accepted (Pearce, 1989). TEV consists of the sum of all market and non-market values in the environment. Alternatively we can think about use-values where activity takes place (e.g. aesthetic value) and non-use values where values are experienced passively (e.g. existence value). Use values may in turn be direct (e.g. recreational diving) or indirect (e.g. assimilation of pollution) (Fig. 3).

\subsection{Monetary valuation}

Not all environmental goods and services are traded on markets. Valuation techniques for non-market environmental goods and services include (i) Revealed Preference (RP) and (ii) Stated Preference (SP) methods. RP techniques analyze actual consumer choices in a market to extract values, which people relate to environment. SP techniques elucidate values, which stakeholders assign to environmental resources or ecosystem services in a hypothetical market. Many of the valuation techniques will only capture some of the values described in Fig. 3. Furthermore, they make the assumption of rational behaviour and perfect information - rarely the case. The most commonly applied valuation techniques useful to EB-MSM include Production Function, Cost of Illness/ Human Capital, Replacement Cost, Travel Cost, Hedonic Pricing, Contingent Valuation (CV), Choice Modelling (CM), and Benefits Transfer (BT) (see Suppl. 2 for details).

The environment is a provider of services supporting the economy and human wellbeing. This worldview builds the thinking of Boulding (1966), and Schumacher (1973) among others. Costanza et al. (1997) published a controversial paper, which estimated the value of global ecosystem services at US\$ 33 trillion $\mathrm{yr}^{-1}$. According to their estimate marine ecosystems have a value almost twice that of all terrestrial ecosystem services. They used the BT method reviewing over 100 valuation studies producing a value per hectare for key global biomes. These results have been challenged by some economists as flawed (World Bank, 2005). Redford and Adams (2009) believe that identifying ecosystem services helps to explain human dependence on nature, but worry that valuation disregards biodiversity. Similarly, Sagoff (2008) suggests that ecosystem valuation confuses 'prices' with 'values'; and that market price ('willingness-to-pay') "does not correlate with value, benefit or utility". However, many others have adopted the approach (Firn 


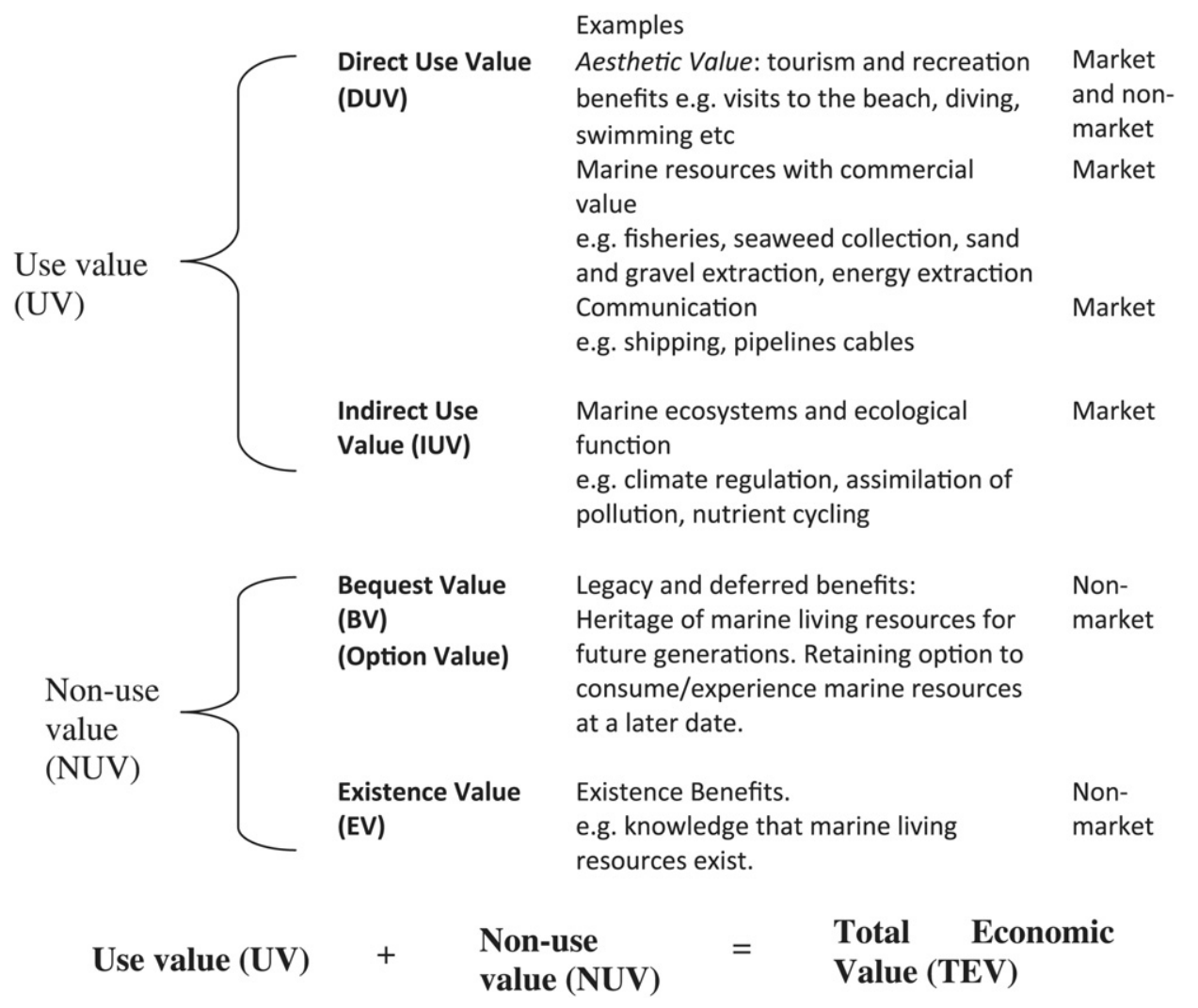

Fig. 3. A typology of potential economic values provided by the management of marine areas.

and McGlashan, 2001; Patterson and Cole, 1999; Pimentel et al., 1997; Williams et al., 2003).

There is a modest but growing body of marine environmental valuation studies, mostly from the US; this work has tended to focus on recreational values of beaches (Ledoux and Turner, 2002; Pendelton et al., 2007). An EU study involving an international call for environmental valuation studies generated 291 responses only 4 of which were marine (Markandya et al., 2008).

Beaumont et al. (2008) attempted to value the ecosystem services of UK marine biodiversity. Despite a lack of reliable data the study helped "raise awareness of the importance of marine biodiversity". However, the authors concluded that the monetary values identified could not be aggregated because different calculation methods had been used. This is a problem as the primary purpose of monetary valuation is to facilitate direct comparison.

There is a clear rationale that underpins the desire to place monetary values on environmental change. Monetary values should allow us to compare environmental costs and benefits with market costs and benefits. Great advances have been made in the development of valuation techniques but methodological limitations and serious theoretical issues remain to be resolved.

\subsection{Non-monetary assessments}

Alternatives to monetary valuation are sought. Rather than producing a single metric, the results of non-monetary assessments guide policy allowing weight to be given to potential areas of conflict and consensus.

Methodologies of non-monetary assessment include Environmental Impact Assessment (EIA), Opinion Polling (OP) and MultiCriteria Analysis (MCA). A development of MCA is Multi-Attribute Decision Analysis, which addresses complex problems characterised by a mix of objectives.
Several developments of MCA techniques have been attempted to achieve a closer reflection of core values. One such is AGORA (Assessment of Group Options with Reasonable Accord), a participatory conflict management algorithm which uses MCA, core theory and game theory. Issues around a collective problem are assessed through a questionnaire designed to an agenda set by the stakeholders themselves (Davos et al., 2007). The focus is to help stakeholders develop cooperation strategies by analysing their priorities.

\subsection{Implications of socioeconomic valuation for EB-MSM}

Any effective EB-MSM regime must understand socioeconomic values. The idea of placing monetary values on the environment is not new. This is most straightforward where market goods, such as fisheries, are being assessed. However, many environmental values are non-market and commentators recognise the difficulty of reducing these to a monetary unit (O'Niel, 1993). Non-monetary valuation techniques attempt to understand the cause, distribution and strength of socioeconomic values. The drive here is to win the widest possible consensus reducing the need for difficult and costly enforcement in the future. Collaborative dimensions to governance identifying core values of stakeholders are essential if EB-MSM is not to be seen as another scientific panacea.

\section{Critical issues}

\subsection{Climate change and EB-MSM}

Temperature increase and the greater frequency of temperature anomalies may involve a series of interrelated problems. Sea level rise, change in the chemical composition of sea water and acidification, modification of the hydrological cycles, increase in the risk 
of coastal erosion and saltwater intrusion, decline of certain habitats, latitudinal range shifts of species, outbreaks of invasive species, effects on species richness, changes on ecosystem functioning and loss of goods and services are among the effects of climate change in the marine environment (Bianchi, 2007; Drinkwater et al., 2010; Harley et al., 2006; IPCC, 2007; Occhipinti-Ambrogi, 2007; Parmesan and Yohe, 2003; Perry et al., 2005; Rosenzweig et al., 2008; Zenetos et al., 2010). All the main marine ecological systems and the human activities therein developed such as fishing and aquaculture, public health, conservation and the tourism industry, are destined to be influenced by climate change (Barange and Perry, 2009; Cochrane et al., 2009; Handisyde et al., 2006).

Because of the uncertainties about the nature of future climate changes, EB-MSM must be alert to change and responsive. Management plans have to be updated on a periodic basis to assess and address possible changes in ecosystems and human uses due to climate change. A clear regulatory framework, allowing for the regular update of environmental targets to take into account the variations caused by climate change is essential. For effective adaptive management, monitoring of changing climate, ecosystem state, and key ecosystem characteristics should be a central component of EB-MSM (Foley et al., 2010). Uncertainty and variability in marine ecosystems because of climate change make it imperative to take a precautionary approach within the planning and governance structure of EB-MSM regimes.

Emphasis should be placed on conservation activities that promote the preservation of species, habitats and ecosystem processes. Networks of MPAs within a broader EB-MSM context are much more resilient to the threats of climate change than single MPAs, as they address uncertainty by spatially spreading potential risks, building redundancies (especially among key species, groups, and drivers of ecosystem structure) and buffer areas, and allowing species to shift their distribution among reserves in response to large scale changes. Networks of MPAs should ensure local integrity, representation and replication of all major habitats particularly at sites that may be more resilient to climate change. The increase of reserve connectivity is the most urgent recommendation for climate change adaptation strategies for biodiversity management, according to the review by Heller and Zavaleta (2009).

Management of fisheries needs flexibility to account for climatic driven changes in stock distribution and abundance, and deal with the unpredictable response of people and ecosystems (Badjeck et al., 2010; Daw et al., 2009; Grafton, 2010). Within an EB-MSM context, it is important to develop approaches that maintain the resilience of populations, communities and ecosystems to the combined and interacting effects of climate change and fishing (Perry et al., 2010).

Adaptation strategies for spatial management of coastal areas should face beach erosion induced by sea-level rise and storm surges. Measures to promote coastal resilience should include protection, regeneration of dune plants and stabilisation, the maintenance of sediment supply and the provision of buffer zones, providing setback zones which would allow the beach to migrate landward as the sea rises (Defeo et al., 2009).

Profound actions to fight climate change by the reduction of greenhouse gas emissions have been in place in the last two decades. A major policy to achieve that is the production of clean energy. Measures for clean energy include the installation of large offshore wind farms and sea tidal turbines, which in many marine areas have substantially increased competition for valuable sea space (e.g. Berkenhagen et al., 2010). EB-MSM provides the framework and regulatory strategies to deal with such increased conflicts between clean energy production and other uses of marine space.

\subsection{Geohazard risks and EB-MSM}

The term geohazard is used to define the geological process or phenomenon that represents or has the potential to develop further into a situation leading to damage or uncontrolled risk. Geohazards to be considered for EB-MSM may include: coastal and submarine landslides and rockfalls, earthquake triggered phenomena (seafloor rupturing, vertical dislocation of coastlines, etc), volcanic and hydrothermal activity, seeping of cold fluids (non-volcanic gas, groundwater discharge, etc), and tsunamis.

Tectonically active areas are characterized by frequently occurring large earthquakes, which may nucleate on- or offshore. Earthquakes nucleated on faults running close to or crosscutting the coastal zone may lead to uplift or subsidence of long sections of the coastline and therefore seriously affect coastal constructions and activities.

Offshore submarine landslides alter significantly the seafloor and are able to trigger tsunamis, which may be catastrophic for the adjacent shores. Coastal sliding or collapse of the coastal zone due to instability may develop aseismically, or be triggered by earthquakes or volcanic activity. In all cases the coastal or submarine landscape can change dramatically, thus affecting the associated human activities and ecosystems.

Sites of submarine volcanism and hydrothermal activity as well as areas with mud volcanism, gas hydrates deposits and seepages of cold fluids (methane, water, etc) are known as extreme environments that host very special ecosystems which are adapted to them. Violent activity of volcanoes, like eruption and magma flow, or massive mud expulsion or dissociation of gas hydrates, are phenomena that can modify the submarine seafloor and the local environmental parameters, and therefore the associated ecosystems.

Although tsunamis are a secondary phenomenon, triggered by other geohazards (earthquakes, slope failures, volcanoes), in many cases have been proved to be the most catastrophic process for coastal areas. Modelling of tsunami generation and propagation has been developed to assess impact on the shore, inundation areas and tsunami run-up (Dawson et al., 2004; Titov and Synolakis, 1998; Weiss et al., 2006; and references therein).

Strategies to take into account geohazard risks in EB-MSM have been applied or proposed worldwide, aiming at protecting from or mitigating the related risk. Since geohazards do not occur uniformly around the globe, not even in regional scale, case- and site-specific studies have to be conducted and respective scenarios and strategies have to be developed in order to design and apply sustainable management. Especially in coastal areas, management plans could include buffer zones to specify the minimum distance for permanent structures to be constructed away from the coastline, rehabilitation plans for coastal ecosystems, livelihood restoration plans, and establishment of a geohazards warning system as an approach to mitigate related disasters. In terms of marine conservation through networks of MPAs, geohazard risk should be taken into account especially in the design phase. In the selection of sites for protection, geohazard risk should be a selection criterion, i.e. sites of low geohazard risk should be favoured when contrasted to high risk sites of equal ecological value.

\section{Conclusions}

EB-MSM is an emerging paradigm of integrative ocean management that recognizes the full array of interactions within an ecosystem including human uses. It is a promising multidisciplinary approach driven by high-level goals described in a number of international, regional and national policies. Using the best available science, EB-MSM aims to the maintenance of marine ecosystems in a healthy condition, the sustainable exploitation of 
ecosystem goods and services, the reduction of conflicts among competing uses of the maritime territory, and the provision of multiple benefits to an as wide as possible array of involved sectors. Such high-level goals need to be translated into more operational objectives before specific targets, limits and measures can be elaborated. Effectiveness is then measured through the processes of monitoring and evaluation of proper indicators against those operational objectives.

Recently several hierarchical frameworks that relate high-level goals to operational objectives have been developed, allowing the integration of data from different disciplines and the combination of views from different sectors. This new perspective on available information promotes active learning and consequent adaptation of management to changing conditions. EB-MSM is also innovative in recognising the wide linkages across marine and coastal ecosystems, addressing uses of the marine environment and their related impacts at a regional scale, and taking into account transboundary issues. Early stakeholder engagement in the management process, rather than final consultation, is another distinctive feature of EB-MSM.

MSP, OZ, MPA networks, and socioeconomic valuation techniques are among the most important tools for EB-MSM. MSP is an integrated planning framework to manage human activities in space and time to deliver on defined planning objectives. $\mathrm{OZ}$ is a set of regulatory measures that partition a region into zones designed to allow or prohibit certain activities. There are many practical tools for OZ, 'Marxan with Zones' being the most popular one. MPA networks are an area-based management tool within EB-MSM providing a means for emphasised protection of features and processes in a given ecosystem that merit site specific management measures. The effectiveness of MPA networks is greatly enhanced if planned within a wider context of EB-MSM that ensures good ecosystem health in the MPA-surrounding environment as well. Both monetary and non-monetary valuation techniques have been developed to evaluate the goods and services of marine ecosystems and guide management decisions in the face of several alternative options, especially in areas of conflict.

EB-MSM constitutes a framework that provides opportunities for several strategies to effectively deal with climate change and geohazard risks. These include the implementation of networks of MPAs, changes in the spatial and temporal allocation of maritime activities, flexibility in the management of fisheries, measures to promote coastal resilience, restoration of critical coastal ecosystems, designation of buffer zones between permanent structures and the coastline, and implementation of monitoring programs and warning systems that can mitigate risks. In addition, adaptive management provides a practical way to tackle uncertainty and allow for adjustment to new conditions or new information.

Practical implementation of EB-MSM faces a number of challenges such as major science and knowledge gaps, constraints in policies and legislation, institutional fragmentation, and difficulties in coupling environmental safety and sustainable use of resources with stakeholder's needs and expectations. Due to the limits of our ability to predict the response of ecosystems to human interventions, any EB-MSM framework must be flexible and able to incorporate changes. Research gaps include the need for a better guidance on how to implement a socioeconomic evaluation into marine spatial management to link the value of ecosystem goods and services to costs of management measures. Valuation techniques need to be further developed in order to better assist maritime policies and EB-MSM frameworks. Lastly, there is a need for further practical guidance on how to assess potential ecological and socioeconomic risks and consequences of future spatial management scenarios, accounting for natural system variability, climate change and geohazards.

\section{Ethical statement}

All authors agree with the contents and to the submission. To our knowledge, no ethical issues are raised.

\section{Acknowledgements}

This work is part of the ongoing research within the EU FP7 program "Monitoring and Evaluation of Spatially Managed Areas" (MESMA; grant number: 226661; www.mesma.org).

\section{Appendix. Supplementary material}

Supplementary data related to this article can be found online at doi:10.1016/j.ocecoaman.2011.09.002.

\section{References}

Agardy, T., 1994. Advances in marine conservation: the role of marine protected areas. Trends Ecol. Evol. 9, 267-270.

Agardy, T., 2005. Global marine conservation policy versus site level implementation: the mismatch of scale and its implications. Mar. Ecol. Prog. Ser. 300, $242-248$.

Agardy, T., 2009. Marine spatial planning in Europe: can MSP help achieve EBM without ocean zoning? Mar. Ecosyst. Manage. 3 (2), 7.

Alder, J., 1996. Have tropical marine protected areas worked? An initial analysis of their success. Coast. Manage. 24 (2), 97-114.

Arkema, K.K., Abramson, S.C., Dewsbury, B.M., 2006. Marine ecosystem-based management: from characterization to implementation. Front. Ecol. Environ. 4, 525-532.

Armitage, D.R., Plummer, R., Berkes, F., Arthur, R.I., Charles, A.T., Davidson-Hunt, I.J., Diduck, A.P., Doubleday, N.C., Johnson, D.S., Marschke, M., McConney, P., Pinkerton, E.W., Wollenberg, E.K., 2009. Adaptive co-management for socialecological complexity. Front. Ecol. Environ. 7, 95-102.

Badjeck, M.-C., Allison, E.H., Halls, A.S., Dulvy, N.K., 2010. Impacts of climate variability and change on fishery-based livelihoods. Mar. Policy 34, 375-383.

Ban, N.C., Alidina, H.M., Ardron, J.A., 2010. Cumulative impact mapping: advances, relevance and limitations to marine management and conservation, using Canada's Pacific waters as a case study. Mar. Policy 34, 876-886.

Barange, M., Perry, R.I., 2009. Physical and ecological impacts of climate change relevant to marine and inland capture fisheries and aquaculture. In: Cochrane, K., De Young, C., Soto, D., Bahri, T. (Eds.), Climate Change Implications for Fisheries and Aquaculture: Overview of Current Scientific Knowledge. FAO Fisheries and Aquaculture Technical Paper No. 530. FAO, Rome, pp. 7-106.

Beaumont, N.J., Austen, M.C., Mangi, C.S., Townsend, M., 2008. Economic valuation and the conservation of marine biodiversity. Mar. Pollut. Bull. 56, 386-396.

Belfiore, S., Barbiere, J., Bowen, R., Cicin-Sain, B., Ehler, C., Mageau, C., McDougall, D. Siron, R., 2006. A Handbook for Measuring the Progress and Outcomes of Integrated Coastal and Ocean Management. IOC Manuals and Guides No. 46, ICAM Dossier, 2. UNESCO, Paris.

Berkenhagen, J., Döring, R., Fock, H.O., Kloppmann, M.H.F., Pedersen, S.A., Schulze, T., 2010. Decision bias in marine spatial planning of offshore wind farms: problems of singular versus cumulative assessments of economic impacts on fisheries. Mar. Policy 34, 733-736.

Bianchi, C.N., 2007. Biodiversity issues for the forthcoming tropical Mediterranean Sea. Hydrobiologia 580, 7-21.

Blæsbjerg, M., Pawlak, J.F., Sørensen, T.K., Vestergaard, O., 2009. TemaNord 2009. Marine Spatial Planning in the Nordic Region - Principles, Perspectives and Opportunities, vol. 528. Nordic Council of Ministers, Copenhagen.

Boulding, K., 1966. The Economics of the Coming Spaceship Earth. In: Jarett, H. (Ed.) 1992, Environmental Quality in a Growing Economy. Johns Hopkins University Press, Baltimore, MD, pp. 3-14.

Cardoso, A.C., Cochrane, S., Doerner, H., Ferreira, J.G., Galgani, F., Hagebro, C., Hanke, G., Hoepffner, N., Keizer, P.D., Law, R., Olenin, S., Piet, G.J., Rice, J. Rogers, S.I., Swartenbroux, F., Tasker, M.L., van de Bund, W., 2010. Scientific Support to the European Commission on the Marine Strategy Framework Directive. Management group report. JRC Scientific and Technical Reports. Office for Official Publications of the European Communities, Luxembourg.

Carollo, C., Reed, D.J., Ogden, J.C., Palandro, D., 2009. The importance of data discovery and management in advancing ecosystem-based management. Mar. Policy 33, 651-653.

Chadwick, D.H., 1996. National wildlife refuges. Natl. Geogr. 190, 2-35.

Cinner, J.E., Aswani, S., 2007. Integrating customary management into marine conservation. Biol. Conserv. 140, 201-216.

Cochrane, K., De Young, C., Soto, D., Bahri, T., 2009. Climate Change Implications for Fisheries and Aquaculture: Overview of Current Scientific Knowledge. FAO Fisheries and Aquaculture Technical Paper No. 530. FAO, Rome. 
Costanza, R., d'Arge, R., de Groot, R., Farber, S., Grasso, M., Hannon, B., Limburg, K., Naeem, S., O’Neill, R.V., Paruelo, J., Raskin, R.G., Sutton, P., van den Belt, M., 1997. The value of the world's ecosystem services and natural capital. Nature 387, $253-260$.

Crowder, L., Norse, E., 2008. Essential ecological insights for marine ecosystembased management and marine spatial planning. Mar. Policy 32, 772-778.

Curtin, R., Prellezo, R., 2010. Understanding marine ecosystem based management: a literature review. Mar. Policy 34, 821-830.

Davos, C., Siakavara, K., Santorineou, A., Side, J., Taylor, M., Barriga, P., 2007. Zoning of marine protected areas: conflicts and cooperation options in the Galapagos and san Adres archipelagos. Ocean Coast. Manage. 50, 223-252.

Daw, T., Adger, W.N., Brown, K., Badjeck, M.C., 2009. Climate change and capture fisheries: potential impacts, adaptation and mitigation. In: Cochrane, K. De Young, C., Soto, D., Bahri, T. (Eds.), Climate Change Implications for Fisheries and Aquaculture: Overview of Current Scientific Knowledge. FAO Fisheries and Aquaculture Technical Paper No. 530. FAO, Rome, Italy, pp. 107-150.

Dawson, A.G., Lockett, P., Shi, S., 2004. Tsunami hazards in Europe. Environ. Int. 30 $577-585$.

Day, J., 2002. Zoning: lessons from the great barrier reef marine Park. Ocean Coast. Manage. 45, 139-156.

Day, J., 2008. The need and practice of monitoring, evaluating and adapting marine planning and management-lessons from the Great Barrier Reef. Mar. Policy 32 $823-831$

Defeo, O., McLachlan, A., Schoeman, D.S., Schlacher, T.A., Dugan, J., Jones, A., Lastra, M., Scapini, F., 2009. Threats to sandy beach ecosystems: a review. Estuar. Coast. Shelf Sci. 81, 1-12.

Derous, S., Agardy, T., Hillewaert, H., Hostens, K., Jamieson, G., Lieberknetch, L Mees, J., Moulaert, I., Olenin, S., Paelinckx, D., Rabaut, M., Rachor, E., Roff, J. Steinen, E.W.M., Wal, J.T., Lancker, V., Verfaillie, E., Vinx, M., Weslawski, J.M., Degraer, S., 2007a. A concept of biological valuation in the marine environment. Oceanologia 49 (1), 99-128.

Derous, S., Austen, M., Claus, S., Dann, N., Dauvin, J., Deneudt, K., Depestele, J., Desroy, N., Heeses, H., Hostens, K., Marboe, M.P., Moulaert, I., Paelinckx, D. Rabaut, M., Rees, H., Ressurrecao, A., Roff, J., Santos, P.T., Speybroeck, J. Steinen, E.W.M., Tatarek, A., Hofstede, R.T., Vinx, M., Zarycki, T., Degraer, S. 2007b. Building on the concept of biological valuation with respect to translating it to a practical protocol: viewpoints derived from a joint ECORA-MARBEF initiative. Oceanologia 49 (4), 1-8.

Dobson, A., 1996. Environmental sustainabilities: an analysis and a typology Environ. Polit. 5 (3), 401-428.

Douvere, F., 2008. The importance of marine spatial planning in advancing ecosystem-based sea use management. Mar. Policy 32, 762-771.

Douvere, F., 2010. Marine spatial planning: concepts, current practice and linkages to other management approaches. PhD thesis, Ghent University, Belgium.

Douvere, F., Ehler, C., 2008. Special volume: the role of marine spatial planning in implementing ecosystem-based, sea use management. Introduction. Mar. Policy 32, 759-761.

Douvere, F., Ehler, C.N., 2011. The importance of monitoring and evaluation in adaptive maritime spatial planning. J. Coast. Conserv. 15, 305-311.

Drinkwater, K.F., Beaugrand, G., Kaeriyama, M., Kim, S., Ottersen, G., Perry, R.I., Portner, H.O., Polovina, J.J., Takasuka, A., 2010. On the processes linking climate to ecosystem changes. J. Marine Syst. 79, 374-388.

Dudley, N. (Ed.), 2008. Guidelines for Applying Protected Area Management Categories. IUCN, Gland, Switzerland.

EC, 1992. Council Directive on the Conservation of Natural Habitats and of Wild Fauna and Flora. European Commission. Directive 92/43/EEC, OJ L 206.

EC, 2000. Directive of the European Parliament and of the Council Establishing a Framework for Community Action in the Field of Water Policy European Commission, Directive 2000/60/EC, OJ L 327.

EC, 2001. Directive of the European Parliament and of the Council on the Assessment of the Effects of Certain Plans and Programmes on the Environment European Commission, Directive 2001/42/EC, OJ L 197.

EC, 2006. Green Paper: Towards a Future Maritime Policy for the Union: A European Vision for the Oceans and Seas. European Commission, COM, p. 275.

EC, 2008a. Roadmap for Maritime Spatial Planning: Achieving Common Principles in the EU. European Commission, Communication from the Commission, COM, p. 791

EC, 2008b. Directive of the European Parliament and the Council Establishing a Framework for Community Action in the Field of Marine Environmental Policy (Marine Strategy Framework Directive). European Commission. Directive 2008 56/ EC, OJ L 164

EC, 2009. Directive of the European Parliament and the Council on the Conservation of Wild Birds. European Commission. Directive 2009/147/EC, OJ L 20.

EC, 2010. Decision on Criteria and Methodological Standards on Good Environmental Status of Marine Waters. European Commission. Decision 2010/477/EU, OJ L 232.

Ehler, C., 2008. Conclusions: benefits, lessons learned, and future challenges of marine spatial planning. Mar. Policy 32, 840-843.

Ehler, C., Douvere, F., 2007. Visions for a Sea Change. Report of the First International Workshop on Marine Spatial Planning. Intergovernmental Oceanographic Commission and Man and the Biosphere Programme. IOC Manual and Guides No. 48, UNESCO, Paris.

Ehler, C., Douvere, F., 2009. Marine Spatial Planning: A Step-by-Step Approach toward Ecosystem-Based Management. Intergovernmental Oceanographic Commission and Man and the Biosphere Programme. IOC Manual and Guides No. 53, ICAM Dossier No. 6. UNESCO, Paris.
Ekebom, J., Reker, J., Jäänheimo, J. (Eds.), 2008. Towards Marine Spatial Planning in the Baltic Sea Technical Summary Report 4, BALANCE Interreg IIIb project.

FAO, 1995. Code of Conduct for Responsible Fisheries. FAO, Rome.

FAO, 1996. Precautionary Approach to Capture Fisheries and Species Introductions. FAO Tech. Guidelines for responsible fisheries No. 2. FAO, Rome.

Fernandes, L., Day, J., Lewis, A., Slegers, S., Kerrigan, B., Breen, D., Cameron, D., Jago, B. Hall, J., Lowe, D., Innes, J., Tanzer, J., Chadwick, V., Thompson, L., Gorman, K., Simmons, M., Barnett, B., Sampson, K., De'ath, G., Mapstone, B., Marsh, H., Possingham, H., Ball, I., Ward, T., Dobbs, K., Aumend, J., Slater, D., Stapleton, K., 2005. Establishing representative no-take areas in the Great Barrier Reef: large-scale implementation of theory on marine protected areas. Conserv. Biol. 19, 1733-1744.

Firn, J., McGlashan, D., 2001. An Initial Assessment of the Socio-economic and Environmental Benefits from ICZM in Scotland. Scottish Coastal Forum Report, Edinburgh.

Foley, M.M., Halpern, B.S., Micheli, F., Armsby, M.H., Caldwell, M.R., Crain, C.M., Prahler, E., Rohr, N., Sivas, D., Beck, M.W., Carr, M.H., Crowder, L.B., Duffy, J.E., Hacker, S.D., McLeod, K.L., Palumbi, S.R., Peterson, C.H., Regan, H.M., Ruckelshaus, M.H., Sandifer, P.A., Steneck, R.S., 2010. Guiding ecological principles for marine spatial planning. Mar. Policy 34, 955-966.

Francis, T.B., Levin, P.S., Harvey, C.J., 2011. The perils and promise of futures analysis in marine ecosystem-based management. Mar. Policy 35, 675-681.

Fulton, E.A., Smith, A.D.M., Punt, A.E., 2005. Which ecological indicators can robustly detect effects of fishing? ICES J. Mar. Sci. 62, 540-551.

Gaines, S.D., White, C., Carr, M.H., Palumbi, S.R., 2010. Designing marine reserve networks for both conservation and fisheries management. Proc. Natl. Acad. Sci. USA 107, 18286-18293.

Gallangher, R., Carpenter, B. (Eds.), 1997, Human-dominated Ecosystems. A Special Report, vol. 277. Science, pp. 485-525.

Garcia, S.M., Zerbi, A., Aliaume, C., Do Chi, T., Lasserre, G., 2003. The Ecosystem Approach to Fisheries. Issues, Terminology, Principles, Institutional Foundations, Implementation and Outlook. FAO Fisheries Technical Paper No. 443. FAO, Rome.

García-Charton, J.A., Pérez-Ruzafa, A., Marcos, C., Claudet, J., Badalamenti, F., Benedetti-Cecchi, L., Falcón, J.M., Milazzo, M., Schembri, P.J., Stobart, B. Vandeperre, F., Brito, A., Chemello, R., Dimech, M., Domenici, P., Guala, I., Le Diréach, L., Maggi, E., Planes, S., 2008. Effectiveness of European AtlantoMediterranean MPAs: do they accomplish the expected effects on populations, communities and ecosystems? J. Nat. Conserv. 16 (4), 193-221.

Gilliland, P.M., Laffoley, D., 2008. Key elements and steps in the process of developing ecosystem-based marine spatial planning. Mar. Policy 32, 787-796.

Grafton, Q.R., 2010. Adaptation to climate change in marine capture fisheries. Mar Policy 34, 606-615.

Grafton, R.G., Kompas, T., 2005. Uncertainty and the active adaptive management of marine reserves. Mar. Policy 29 (5), 471-479.

Guidetti, P., Milazzo, M., Bussotti, S., Molinari, A., Murenu, M., Pais, A., Spanò, N., Balzano, R., Agardy, T., Boero, F., Carrada, G., Cattaneo-Vietti, R., Cau, A., Chemello, R., Greco, S., Manganaro, A., Notarbartolo di Sciara, G., Russo, G.F., Tunesi, L., 2008. Italian marine reserve effectiveness: does enforcement matter? Biol. Conserv. 141, 699-709.

Halpern, B.S., Walbridge, S., Selkoe, K.A., Kappel, C.V., Micheli, F., D’Agrosa, C., Bruno, J., Casey, K.S., Ebert, C., Fox, H.E., Fujita, R., Heinemann, D., Lenihan, H.S., Madin, E.M.P., Perry, M., Selig, E.R., Spalding, M., Steneck, R., Watson, R., 2008a. A global map of human impact on marine ecosystems. Science 319, 948-952.

Halpern, B.S., McLeod, K.L., Rosenberg, A.A., Crowder, L.B., 2008b. Managing for cumulative impacts in ecosystem-based management through ocean zoning. Ocean Coast. Manage. 51, 203-211.

Halpern, B.S., Lester, S.E., McLeod, K.L., 2010. Placing marine protected areas onto the ecosystem-based management seascape. Proc. Natl. Acad. Sci. USA 107, $18312-18317$.

Handisyde, N.T., Ross, L.G., Badjeck, M.-C., Allison, E.H., 2006. The Effects of Climate Change on World Aquaculture: A Global Perspective. Final Technical Report, DFID Aquaculture and Fish Genetics Research Programme. Stirling Institute of Aquaculture, Stirling, U.K.

Harley, C.D.G., Hughes, A.R., Hultgren, K.M., Miner, B.G., Sorte, C.J.B., Thornber, C.S., Rodriguez, L.F., Tomanek, L., Williams, S.L., 2006. The impacts of climate change in coastal marine systems. Ecol. Lett. 9, 228-241.

Harrop, S.R., 2011. Living in harmony with nature? Outcomes of the 2010 Nagoya conference of the convention on biological diversity. J. Environ. Law 23,117-128.

Heller, N.E., Zavaleta, E.S., 2009. Biodiversity management in the face of climate change: a review of 22 years of recommendations. Biol. Conserv. 142, 14-32.

Holmes, B., 1994. Biologists sort the lessons of fisheries collapse. Science 264, 1252-1253.

ICES, 2005. Guidance on the Application of the Ecosystem Approach to Management of Human Activities in the European Marine Environment. ICES Cooperative Research Report 273.

IPCC, 2007. Climate Change 2007: Synthesis Report. Inter-Governmental Panel on Climate Change.

IUCN-WCPA, 2008. Establishing Marine Protected Area Networks - Making It Happen. IUCN World Commission on Protected Areas. National Oceanic and Atmospheric Administration and the Nature Conservancy, Washington, D.C.

Jameson, S.C., Tupper, M.H., Ridley, J.M., 2002. The three screen doors: can marine "protected" areas be effective? Mar. Pollut. Bull. 44, 1177-1183.

Jones, G., 2000. Outcomes-based evaluation of management for protected areas a methodology for incorporating evaluation into management plans. In: The Design and Management of Forest Protected Areas. Papers Presented at the 
"Beyond the Trees Conference" 8-11 May 2000. WWF, Switzerland, Bangkok, Thailand, pp. 349-358.

Kaiser, M.J., 2005. Are marine protected areas a red herring or fisheries panacea? Can. J. Fish. Aquat. Sci. 62 (5), 1194-1199.

Kelleher, G., Bleakey, C., Wells, S., 1995. A Global Representative System of Marine Protected Areas. Great Barrier Reef Marine Park Authority, IUCN and World Bank, Washington DC.

Kerr, S., Johnson, K., Side, J., Baine, M., Davos, C., Henley, J., 2006. Resolving conflicts in selecting a programme of fisheries science investigation. Fish. Res. 79, 313-324.

Ledoux, L., Turner, R.K., 2002. Valuing ocean and coastal resources: a review of practical and issues for further action. Ocean Coast. Manage. 45, 583-616.

Levin, P.S., Fogarty, M.J., Murawski, S.A., Fluharty, D., 2009. Integrated Ecosystem Assessments: Developing the Scientific Basis for Ecosystem-based Management of the Ocean. PLoS Biology 7: e1000014.

Ludwig, D.R., Hilborn, R., Walters, C.J., 1993. Uncertainty, resources exploitation and conservation: lessons from history. Science 260, 17-36.

Maes, F., 2008. The international legal framework for marine spatial planning. Mar. Policy 32, 797-810.

Mangel, M., Talbot, L.M., Meffe, G.K., Agardy, M.T., Alverson, D.L., Barlow, J., Botkin, D.B., Budowski, G., Clark, T., Cooke, J., Crozier, R.H., Dayton, P.K., Elder, D.L., Fowler, C.W., Funtowicz, S., Giske, J., Hofman, R.J., Holt, S.J., Kellert, S.R., Kimball, L.A., Ludwig, D., Magnusson, K., Malayang, B.S., Mann, C., Norse, E.A., Northridge, S.P., Perrin, W.F., Perrings, C., Peterman, R.M., Rabb, G.B., Regier, H.A., Reynolds, J.E., Sherman, K., Sissenwine, M.P., Smith, T.D., Starfield, A., Taylor, R.J., Tillman, M.F., Toft, C., Twiss, J.R., Wilen, J., Young, T.P., 1996. Principles for the conservation of wild living resources. Ecol. Appl. 6, 338-362.

Markandya, A., Nunes, P.A.L.D., Brauer, I., ten Brink, P., Kuik, O., Rayment, M., 2008. Review on the Economics of Biodiversity Loss - Economic Analysis and Synthesis (Final report to the European Commission, Venice, Italy).

McClanahan, T.R., 1999. Is there a future for coral reef parks in poor tropical countries? Coral Reefs 18 (4), 321-325.

McLeod, K.L., Lubchenco, J., Palumbi, S.R., Rosenberg, A.A., 2005. Scientific Consensus Statement on Marine Ecosystem-Based Management Signed by 221 academic scientists and policy experts with relevant expertise and published by the Communication Partnership for Science and the Sea.

Moilanen, A., Wilson, K.A., Possingham, H.P. (Eds.), 2009. Spatial Conservation Prioritization. Oxford University Press, New York.

Naess, A., 1985. Identification as a source of deep ecological attitudes. In: Tobias, M. (Ed.), Deep Ecology. Avant Books, New York, pp. 256-270.

Norse, E.A., Grimes, C.B., Ralston, S., Hilborn, R., Castilla, J.C., Palumbi, S.R., Fraser, D., Kareiva, P., 2003. Marine reserves: the best option for our oceans? Front. Ecol. Environ. 1 (9), 495-502.

Nunes, P.A.L.D., van den Bergh, J.C.J.M., 2001. Economic valuation of biodiversity: sense or nonsense? Ecol. Econ. 39 (2), 203-222.

Occhipinti-Ambrogi, A., 2007. Global change and marine communities: alien species and climate change. Mar. Pollut. Bull. 55, 342-352.

Ojeda-Martínez, C., Giménez Casalduero, F., Bayle-Sempere, J.T., Cebrián, C.B., Valle, C., Sanchez-Lizaso, J.L., Forcada, A., Sanchez-Jerez, P., Martín-Sosa, P., Falcón, J.M. Salas, F., Graziano, M., Chemello, R., Stobart, B., Cartagena, P., Pérez-Ruzafa, A., Vandeperre, F., Rochel, E., Planes, S., Brito, A., 2009. A conceptual framework for the integral management of marine protected areas. Ocean Coast. Manage. 52, 89-101.

O'Niel, J., 1993. Ecology Politics and the Environment. Routledge, London.

Parfit, M., 1995. Diminishing returns. Exploiting the ocean's bounty. Natl. Geogr. 188, 2-37.

Parma, A.M., Amarasekare, P., Mangel, M., Moore, J., Murdoch, W.W., Noonburg, E., Pascual, M.A., Possingham, H.P., Shea, K., Wilcox, C., Yu, D., 1998. What can adaptive management do for our fish, forests, food, and biodiversity? Integr. Biol. 1, 16-26.

Parmesan, C., Yohe, G., 2003. A globally coherent fingerprint of climate change impacts across natural systems. Nature 421, 37-42.

Patterson, M., Cole, A., 1999. Assessing the Value of New Zealand's Biodiversity. School of Resources and Environmental Planning, Massey University.

Pearce, D., 1989. Blueprint for a Green Economy. Earthscan, London.

Pendelton, L., Atiyah, P., Moorthy, A., 2007. Is the non-market literature adequate to support costal and marine management? Ocean Coast. Manage. 50, 363-378.

Perry, A.L., Low, P.J., Ellis, J.R., Reynolds, J.D., 2005. Climate change and distribution shifts in marine fishes. Science 208, 1912-1915.

Perry, R.I., Cury, P., Brander, K., Jennings, S., Mollmann, C., Planque, B., 2010. Sensitivity of marine systems to climate and fishing: concepts, issues and management responses. J. Marine Syst. 79, 427-435.

Pimentel, D., Wilson, C., McCullum, C., Haung, R., Dwen, P., Flack, J., Tran, Q., Saltman, T., Cliff, B., 1997. Economic and environmental benefits of biodiversity. Bioscience 47, 747-757.

Platt, J.R., 1964. Strong interference. Science 146, 347-353.

Pomeroy, R.S., Douvere, F., 2008. The engagement of stakeholders in the marine spatial planning process. Mar. Policy 32, 816-822.

Pomeroy, R.S., Parks, J.E., Watson, L.M., 2004. How Is Your MPA Doing? A Guidebook of Natural and Social Indicators for Evaluating Marine Protected Area Management Effectiveness. IUCN, Gland, Switzerland and Cambridge, UK.

Pomeroy, R.S., Watson, L.M., Parks, J.E., Cid, G.A., 2005. How is your MPA doing? A methodology for evaluating the management effectiveness of marine protected areas. Ocean Coast. Manage. 48, 485-502.
Redford, K.H., Adams, W.M., 2009. Payment for ecosystem services and challenges of saving nature. Conserv. Biol. 23 (4), 785-787.

Rice, J., de Fátima Borges, M., Grehan, A., Kenny, A., Loeng, H., Maynou, F., Serrão Santos, F., Skjoldal, H.R., Thébaud, O., Vassilopoulou, V., Volckaert, F., Curtil, O., Levrel, H., Carbonnière, A., 2010. Science Dimensions of an Ecosystem Approach to Management of Biotic Ocean Resources (SEAMBOR) Marine Board-ESF/ICES/ EFARO Position Paper 14.

Roberts, C.M., 1997. Connectivity and management of Caribbean coral reefs. Science 278, 1454-1457.

Roberts, C.M., Andelman, S., Branch, G., Bustamante, R.H., Castilla, J.C., Dugan, J., Halpern, B.S., Lafferty, K.D., Leslie, H., Lubchenco, J., McArdle, D., Possingham, H.P., Ruckelshaus, M., Warner, R.R., 2003. Ecological criteria for evaluating candidate sites for marine reserves. Ecol. Appl. 13, 199-214.

Rogers, S.I., Tasker, M.L., Earll, R., Gubbay, S., 2007. Ecosystem objectives to support the UK vision for the marine environment. Mar. Pollut. Bull. 54, 128-144.

Rosenzweig, C., Karoly, D., Vicarelli, M., Neofotis, P., Wu, Q., Casassa, G., Menzel, A., Root, T.L., Estrella, N., Seguin, B., Tryjanowski, P., Liu, C., Rawlins, S., Imeson, A 2008. Attributing physical and biological impacts to anthropogenic climate change. Nature 453, 353-358.

Ruddle, K., Hickey, F.R., 2008. Accounting for the mismanagement of tropical nearshore fisheries. Environ. Dev. Sustain 10, 565-589.

Sagoff, M., 2008. On the economic value of ecosystem services. Environ. Value 17, $239-257$.

Sainsbury, K.J., Punt, A.E., Smith, A.D.M., 2000. Design of operational management strategies for achieving fishery ecosystem objectives. ICES J. Mar. Sci. 57, 731-741.

Sala, E., Aburto-Oropeza, O., Paredes, G., Parra, I., Barrera, J.C., Dayton, P.K., 2002. A general model for designing networks of marine reserves. Science 298, 1991-1993.

Salpin, C., Germani, V., 2010. Marine protected areas beyond areas of national jurisdiction: what's mine is mine and what you think is yours is also mine. Rev. Eur. Comm. Int. Env. Law 19 (2), 174-184.

Sanchirico, J.N., Eagle, J., Palumbi, S., Thompson, B., 2010. Comprehensive planning dominant-use zones, and user rights: a new era in ocean governance. B. Mar. Sci. 86, 273-285.

Schumacher, E.F., 1973. Small Is Beautiful: A Study of Economics as if People Mattered. Blond Briggs, London.

Seabright, P., 1993. Managing Local Commons: theoretical issues in incentive design. J. Econ. Perspect. 7, 113-134.

Shipp, R.L., 2003. A perspective on marine reserves as a fishery management tool. Fisheries 28 (12), 10-21.

Sobel, J., Dahlgren, C. (Eds.), 2004. Marine Reserves: A Guide to Science, Design, and Use. Island Press, Washington, D.C.

Steele, J.H., Beet, A.R., 2003. Marine protected areas in 'nonlinear' ecosystems. P. Roy. Soc. B. . Biol. Sci. 270, S230-S233.

Stelzenmüller, V., Lee, J., South, A., Rogers, S.I., 2010. Quantifying cumulative impacts of human pressures on the marine environment: a geospatial modelling framework. Mar. Ecol. Prog. Ser. 398, 19-32.

Tallis, H., Levin, P.S., Ruckelshaus, M., Lester, S.E., McLeod, K.L., Fluharty, D.L. Halpern, B.S., 2010. The many faces of ecosystem-based management: making the process work today in real places. Mar. Policy 34, 340-348.

Ter Hofstede, R., Bos, O., van Dalfsen, J., Jones, P., Katsanevakis, S., Sutton, G., Rabaut, M., South, A., Stelzenmuller, V., Vincx, M., 2010. MESMA: It's all about weighing interests. ICES Annual Science Conference, 20-24 September 2010, Nantes, France, pp. 289-290.

Titov, V., Synolakis, C.E., 1998. Numerical modelling of tidal wave runup. J. Waterw. Port C. ASCE 124 (4), 157-171.

Walters, C.J., Hilborn, R., 1976. Adaptive control of fishing systems. J. Fish. Res. Board. Can. 33, 145-159.

Walters, C.J., Maguire, J.J., 1996. Lessons for stock assessment from the northern cod collapse. Rev. Fish Biol. Fisher. 6, 125-137.

Watts, M.E., Ball, I.R., Stewart, R.S., Klein, C.J., Wilson, K., Steinback, C., Lourival, R., Kircher, L., Possingham, H.P., 2009. Marxan with Zones: software for optimal conservation based land- and sea-use zoning. Environ. Modell. Softw. 24, 1513-1521.

Weiss, R., Wünnemann, K., Bahlburg, H., 2006. Numerical modelling of generation, propagation and run-up of tsunamis caused by oceanic impacts: model strategy and technical solutions. Geophys. J. Int. 167 (1), 77-88.

Williams, E., Firn, J.R., Kind, V., Robers, M., McGlashan, D., 2003. The value of Scotland's ecosystem services and natural capital. Eur. Env. 13 (2), 67-78.

World Bank, 2005. How Much Is an Ecosystem Worth: Assessing the Economic Value of Conservation. World Bank, Washington DC.

Zabala, M., 1999. Recreation in Mediterranean marine parks: limits and perspectives. Proc. Scientific Des. Monit. Mediterr. Marine Protected Areas, 51-59. Porto Cesareo, 21-24 Oct. 1999.

Zenetos, A., Gofas, S., Verlaque, M., Çinar, M.E., García Raso, E., Azzurro, E., Bilecenoğlu, M., Froglia, C., Siokou, I., Bianchi, C.N., Morri, C., Sfriso, A., San Martin, G., Giandgrande, A., Katağan, T., Ballesteros, E., Ramos-Esplá, A. Mastrototaro, F., Ocaña, O., Zingone, A., Gambi, M.C., Streftaris, N., 2010. Alien species in the Mediterranean Sea by 2010. A contribution to the application of European Union's marine strategy framework directive (MSFD). Part I. Spatial distribution. Mediterr. Mar. Sci. 11 (2), 381-493. 